\title{
THE HISTORY OF AL-MATURIDY THEOLOGY IN THE VOLGA REGION
}

\author{
Ramil Adigamov \\ Bolgar Islamic Academy, BOLGAR \\ abu_muhammad@mail.ru
}

\begin{abstract}
Al-Maturidy theology has been considered as a traditional creed for many regions in the world, including Volga region of Russia. Throughout the Soviet period, Muslims in Volga were forced to practice their religion in secretive manner, which eventually caused an interruption in the chain of spiritual continuity. But, after the collapse of the Soviet Union, Muslims in Volga started to return to their ethnoconfessional tradition. At the same time, the theological tradition had to compete with the Salafi ideology which begun to arrive in the region from abroad. As such has triggered the Muslim proponents of Maturidy traditions to reclaim their heritage. This study aims at tracing the historical process of the origin and development of Maturidy thought in the Volga-Ural region. It uses descriptive and comparative methods and the theory of continuity and changes. Observing the chronological sequence, the study traces the process of the origin and development of Maturidy ideology. The chronological scope of this study is limited by the period from the tenth century until our time. The study reveals that the al-Maturidy's teachings in the region for all periods of historical development have experienced five periods. Three periods show a rapid development stage and two periods experience a decline.
\end{abstract}

\footnotetext{
Abstrak : Al-Maturidy merupakan ajaran tradisional yang berlaku di beberapa wilayah di dunia, termasuk wilayah Volga di Rusia. Sepanjang periode Soviet, umat Islam di Volga dipaksa untuk mempraktikkan agama mereka secara rahasia, yang akhirnya menyebabkan terputusnya rantai kesinambungan spiritual. Namun setelah runtuhnya Uni Soviet, umat Islam di Volga mulai kembali pada tradisi lama mereka. Pada saat yang sama, teologi tradisional harus bersaing dengan ideologi Salafi yang
} 
muncul dari luar negeri. Para pendukung Muslim tradisional Maturidy mulai mengambil kembali warisan mereka. Penelitian ini bertujuan untuk melacak proses historis asal dan perkembangan pemikiran Maturidy di wilayah Volga-Ural. Penelitian ini menggunakan metode deskriptif dan komparatif. Memperhatikan urutan kronologisnya, studi ini menelusuri proses asal dan perkembangan ideologi Maturidy. Ruang lingkup kronologis penelitian dibatasi oleh periode dari abad kesepuluh hingga saat ini. Studi ini mengungkapkan bahwa ajaran al-Maturidy di wilayah tersebut telah mengalami lima periode sejarah perkembangan. Tiga periode menunjukkan tahap perkembangan yang cepat dan dua periode mengalami periode penurunan.

Keywords : History, Al-Maturidy, Theology, Volga

\section{A. Introduction}

With the collapse of the Soviet Union after 1991, the official atheistic ideology of the country was in despair, leading to a spiritual vacuum. In order to satisfy the spiritual needs of the population, two trends were formed. The first trend sought to return to spiritual roots and revive the centuries-old heritage of the people. The second trend was based on the recognition of traditions as something that has lost relevance, and on the search for new ideas abroad. As such has in turn trigerred a confrontation between the ideologies of Salafis and Hanafi-Maturidy, with regard to the theological thought of the Volga ${ }^{1}-U$ ral Muslims.

The revival of al-Maturidy ideology in the region has acquired special relevance. This was due, firstly, to the fact that during the existence of the Soviet Union, the spiritual and the chain of generations was interrupted. And, accordingly, understanding of the essence of this ideology was lost. Secondly, the Hanafi-Maturidy doctrine in the region, had for centuries been in close neighborhood with Orthodoxy, as well as with other beliefs. Historical relations between representatives of these religions have acquired tolerant forms that allow maintaining good-neighborly relations.

${ }^{1}$ Central regions of modern Russia. It is a historical region in modern Russia that encompasses the drainage basin of the Volga River, the longest river in Europe, in central and southern European Russia. Depending on the historical period, it was part of the Volga Bulgar, then the Golden Horde, Kazan Khanate, and later the Russian Empire, and Soviet Union. 
As for the Salafi doctrine, since it was formed mainly in mono-ethnic and mono-confessional environment, it needed adaptation. Therefore, its appearance into the region inevitably brought a split among Muslims, and at the same time exacerbated the relationship between the various social groups in the region.

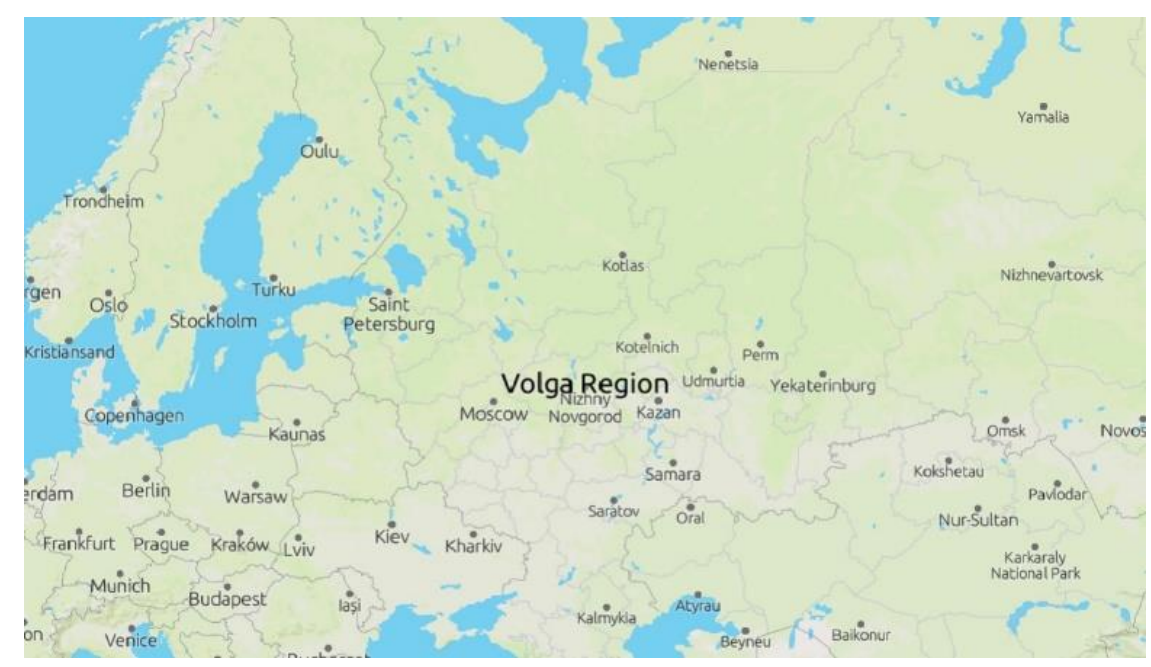

Pic. 1. The Map of Volga Region

In this regard, the purpose of this study is to trace the historical process of the Hanafi-Maturidy creed in Volga region. Using descriptive methods, this study tries to uncovered the al-Maturidy period in this region.

The history and culture of Islam in the Volga region has been revealed in the writings of many Russian scientists ${ }^{2}$ such as Mukhametshin R. M., Izmailov I., Iskhakov D., Garayeva, N., Khabutdinov A., Nugmanov A., Salikhov R., Idiatullina G., D. Usmanov, and many others. Non-Russian scientists who has studied about it include Michael Kemper ${ }^{3}$, H. Irene, I.

${ }^{2}$ See R.M. Mukhametshin, Islam in The Midle Volga Region: History and Modernity (Kazan: The Master Line, 2001).

${ }^{3}$ Michael Kemper, "Sihābuddīn Al-Margānī as a Religious Scholar, Muslim CUlture in Russia and Central Asia From The 18th to The Early 20th Centuries," in Islamic Studies, ed. Michael Kemper, Anke Von Kugelgen, and Dmitry Yermakov (Berlin: Klaus Schwarz Verlag, 1996), p.129-165; See also Michael Kemper, Sufis Und Gelehrte in Tatarien Und Baschkirien, 1789-1899, Der Islamiche Diskurs Unter Russicher Herrschaft (Berlin: Schwarz Verlag, 1998). 
Marash $^{4}$, M. Gormez ${ }^{5}$. Yet, it was the German researcher, Ulrich Rudolf ${ }^{6}$, who has written in great details about the origin of the teachings of $\mathrm{Abu}$ Mansur al-Maturidy. As for the history of the origin and development of this ideology in the Volga region, this problem is raised for the first time.

\section{B. Hostorical Period of al-Maturidy in the Volga Region}

It must be emphasized here that discussing about al-Maturidy in Volga Region means a discussion about Islam itself. Because the history of the development of Islam in this region cannot be separated from the teachings of al-Maturidy.

The history of al-Maturidy's teachings in the Volga region is divided into five periods. They are as follows:

1. The origin of Islam in the Volga region

There are several versions regarding the arrival of Islam in the Volga region. According to some legends, Islam entered the region during the time of the companions of the prophet Muhammad. It was when he sent three of his companions with a Turkic letter written in Arabic letters.

The second version indicates that Islam came to the Volga region from Central Asia. This was due to the preaching work of Muslim merchants who came to the region along the Silk road. The Bulgars who lived in this region gave them the opportunity to trade with peoples who lived in the more Northern regions.

Because there are few several versions regarding to the spread of Islam in the Volga region, it is impossible to pinpoint the start of establishment of al-Maturidy school of the region. But, of course, it chronologically precedes the official adoption of Islam. This fact is proved by the travel notes of Ibn Fadlan in which he wrote about his polemics with

${ }^{4}$ I Marash, Religious Renewal in The Turkic World (1850-1917) (Kazan: Iman, 2005), p.28.

${ }^{5} \mathrm{M}$. Gormez, “Tradition of Novation in Islam and Musa Carullah Bigiyef," in Musa Carullah Bigiyef on The 50th Anniversary of His Death, (Ankara: TRF Publications, 2002), p.123-128; M. Gormez, “Musa Carullah’s Understanding of Sunnah,” in Musa Carullah Bigiyef on the 50th Anniversary of His Death (Ankara: TRF Publications, 2002), p.97-100.

${ }^{6}$ Ulrich Rudolph, Al-Maturidy and The Development of Sunni Theology in Samarqand (Leiden: Brill, 2015), p.362. 
one of the local scholars on various theological issues ${ }^{7}$ which indicates existence of the region's own theological school. So the Bulgars, and later their descendants Tatars got education in the madrasas of Bukhara, Samarkand, Kabul and so on. Returning from there, they became mentors and began to teach students based on the same programs.

Mongol invasion also didn't change the religious orientation of the Volga region because conquerors were very tolerant and, as a result, adopted Islam themselves. Moreover, some of the Mongol khans who converted to Islam made significant contribution to spread and development of Islam in the region. The capital of the Mongolian state of Sarai, was even the center of learning, where many famous theologians, writers, artists and artisans lived. In particular, Sh. Marjani in his historic work "Mustafa al-Akhbar" calls the names of famous Muslim scholars such as Taftazani who not only lived in this town, but even dedicated some of his works to the Mongol khans Berke, Uzbek and others.

\section{Loss of statehood and decline of theological thought}

The conquest of Kazan and Kazan Khanate in the XVI century by Moscow kingdom was a great tragedy for the muslim people state. Statehood was lost, and a large number of material and cultural values were destroyed as well as a significant amount of written spiritual heritage was damaged.

With the fall of Kazan in 1552, the struggle of the Tatar people for their independence continued until 1570. Even after the suppression of the national liberation movement, from time to time there had been uprisings in separate settlements. Moreover, Tatars took part in major uprisings that broke out in various parts of the Russian Empire. Also, there were attempts to find a political solution for the independence problem. Tatars and Bashkirs sent their representatives to Turkey. Because of the fact that during the uprisings of the 1550 - 60s of the XVI century Tatar feudal society was completely destroyed, the resistance movement was led by religious leaders who often became instigators of revolts of the later period. The best examples of it are, the uprisings organized by Mullah Seit in 1681-1684 and the one by Mullah Batyrsha in 1755-1756. All these initiatives were driven

${ }^{7}$ A. Ibn Fadlan, Ibnu Fadlan's Journey to The Volga (Moscow: Publishing House of USSR Academy of Sciences, 1939), p.71.

${ }^{8}$ Sh. Marjani, Mustafad Al-Akhbar Fi Ahvali Kazan and Va Bulgar (Kazan: Domrovskiy, 1900), p.78-89. 
by a desire to preserve the spiritual identity of the Tatars, including alMaturidy doctrine.

Being the leader of the nation, clergy ${ }^{9}$ also played a significant role in identifying the main trends in the development of the Tatar society. Despite the external influence, Tatar society became more and more isolated, seeking to preserve its ethnic and religious identity. The Tatar people turned to religion, language, and religious folk-art as their means to preserve the integrity of their nation and religion. People withdrew into themselves and everything that was outside of the Tatar society was alienated and rejected. This situation was heightened when christianization policy begun to be implemented at 16 centuries by Russian state. It is quite natural that people tried to preserve their national and religious identity, as a result they rendered active ideological and sometimes even armed resistance to Christian missionaries.

\section{Restoration of the position of Islam}

Restoration of the position of Islam and its teachings in the region began after the visit of Empress Catherine II to Kazan in 1767, when she personally removed all previous restrictions on the construction of stone mosques and Tatar public buildings. Subsequently, the historic decree "On the tolerance of religion" signed by the empress in 1773 marked the emergence of religious tolerance in Russia, which also became a prerequisite for the revival of Islam.

Later in 1788, Orenburg Muslim Spiritual Assembly was established to control the Muslim population of the state which put an end to the period of confrontation with Islam and stopped Christianization policy lasting for about 250 years. Taking into account the religious traditions of tatar people, the official structure of the Muslim clergy consisted the following hierarchy: Mufti - Qadi (religious judges) - Akhuns (muhtasibs (imam of a city or region)) - Imam-khatibs (mullahs) - muazzins (azanchy (caller to prayer)). Orenburg Muslim Spiritual Assembly successfully worked until the collapse of the Russian Empire. It should also be noted, that during the reign of Empress Catherine II, the Koran was published for the first time in the history of Islam.

The Volga Islam has predominantly had Central Asian roots and this region is a homeland to people ethnically close to Tatars. This

\footnotetext{
${ }^{9}$ Imams and sufi sheikhs.
} 
connection was very important for Tatars and it continued after the loss of their statehood. This relationship was strengthened after the Tatar settlement (Seitovsky Posad) near Orenburg was established in 1744. It helped to facilitate the trade between the Central Asian states which served as an additional incentive for the education of Tatars in ancient religious centers of Bukhara, Samarkand and others. After the decree on religious tolerance was issued by Catherine II in 1773, Tatar youth began to obtain education in the madrasas of Central Asia. The most famous mentors of that region were Faizhan al-Kabuli (died at 1802) and al-Niyazkul Turkmani (died at 1820/21). They were sheikhs of Naqshbandiyya-mudzhaddidiya brotherhoods and bearers of the Maturidy doctrine. These scholars had significant influence on the formation of views (of what?) of young people from the Volga region who later formed the basis of the Tatar clergy up to the revolution in 1917.

The activities of the famous Tatar theologian Sh. Mardzhani who wrote his own comment to Imam al-Nasafi's "al-Hikma al-Baliga" should be considered the apogee of the pre-revolutionary development of the Maturidy teachings in the Volga region. In the late $19^{\text {th }}$ and early 20th centuries, the Salafi ideology began to appear in the region. This ideology was presented in the works of M. Bigiyev, R. Fakhrutdinov and others. The works of $\mathrm{Z}$. Kamali who made an attempt to rational and philosophical explanation of the basics of Islam are also worth mentioning ${ }^{10}$.

\section{Ideology of Maturidy during militant atheism}

During this period, Islam in the Soviet Union was persecuted like other religions in the region. Practice of Islam was condemned, and a lot of mosques and Muslim schools were closed or even destroyed ${ }^{11}$. In Tatarstan by 1930 more than 10,000 of 12,000 mosques were closed, about $95 \%$ of the mullahs and muazzins were unable to perform their duties. Many spiritual leaders were persecuted, executed and sent to labor camps while some of them migrated abroad. Despite the fact that the materialist ideology was not able to completely eradicate the religious outlook of the people, it has changed the course of history for many decades and formed in the Tatars cautious and sometimes even contemptuous attitude towards religion.

${ }^{10} \mathrm{R}$. Adygamov et al., The History of Islamic Thought in The Volga-Ural Region (Kazan: Institute of History, 2011), p.372.

${ }^{11}$ R.M. Mukhametshin, Tatars and Islam in The XX Century (Kazan: TBP, 2003), p.58. 
However, part of the Tatars remained faithful to their traditions following the instructions of the so called "unofficial" national clergy, who was forced to meet the religious needs of the people secretly. It was this clergy who became the bearer of the Maturidy ideas in the region. They were mostly informal spiritual leaders who were educated in madrasas and had prerevolutionary qualifications to the position of imams. However, under the new conditions they had to conduct their research and teaching activities underground, teaching only the most reliable believers.

The attitude towards religion changed during the war, and since 1944 four independent centers began to implement the Muslim policy of the Soviet Union: first of them is Muslim Spiritual Board of Central Asia and Kazakhstan, located in Tashkent; the second is Muslim Spiritual Board of the Caucasus in Baku; the third is Muslim Spiritual Board of the North Caucasus in Makhachkala; and the fourth is Muslim Spiritual Board of the European part of the USSR and Siberia in Ufa ${ }^{12}$ In 1945 the famous Bukhara madrasa "Mir Arab" resumed its work and continued to educate the clergy.

In the postwar period (60-es) until the collapse of the Soviet Union Abdulkhak Hazrat Sadykov and Akhmadzaki Hazrat who were experts in the fundamentals of Islam not only in Kazan, but in the whole Tatarstan played significant role in spreading the teachings of al-Maturidy. Educational work was conducted secretly in family's homes and involved only the most reliable people ${ }^{13}$.

Akhmadzaki - Sheikh Ahmad Zaki Hazrat Ibn Al-Safiullah Alishi AlMurasavi was born in 1898 in the Murasa village of Chistopol County. His father died when he was 5 years old, and his mother put him to the famous "Kizlyavi" madrasa located close to Chistopol. This madrasah had a good education system. After the successful graduation from the madrasa Ahmad Zaki Hazrat was appointed as imam of the mosque in his native village by Orenburg Muslim Spiritual Assembly. After the revolution, he was forced to immigrate to the Central Asia for a short period of time and after his return to Tatarstan settled in Kazan and worked in various organisations, but still remained loyal to his faith. He continued his preaching work only in the early

\footnotetext{
${ }^{12}$ See the publishing the book of the mufty Gabdrahman Rasulev "The Islam" wich published in Moscow in 1945 G. Rasulev, The Islam (Chelybinsk: The Trust, 2014), p.75.

${ }^{13}$ Oral evidence: Rector of KHMM "Muhammadiya" Yarullin N. muhtasib of Kazan Zalyaletdinov M., imam of the mosque "Sultan" Bikchantaev K.
} 
60s. In 1978 he was appointed as the second imam of the "al-Marjani" mosque and worked there until his death in June 1995. ${ }^{14}$

Abdulkhak Hazrat Sadikov was born in December 1895. He graduated from the madrasa in Tuntar village. He participateds in the First World War and the Second World War and after that worked as a blacksmith and a carpenter in different organizations until the 60 s when he began to preach. He died on January 28 in 1990.

Ahmadzaki Hazrat and Abdulkhak Hazrat are the mentors of such well-known Muslim leaders of Russia as mufti Talgat Tajuddin, qadi Abdulkhak Hazrat Samatov and imam Kamil Bikchantaev.

5. The Maturidy in present time

In the last years of the Soviet Union which marked the era of "glasnost" (freedom of speach) and "perestroika" (political renovation), Islam began to revived. The significant event of this period was the 1100th anniversary of adoption of Islam in Russia celebrated in 1989.

After the collapse of socialism and the Soviet Union in 1991 the extraordinary revival of Islam started in Tatarstan. The pre-revolutionary mosques were restored in many districts of the Republic as well as new mosques were built and madrasas started their educational activities. ${ }^{15}$ However, at the same time, because of the spiritual vacuum, non-traditional Salafi doctrine preached by representatives of various foreign funds began to appear in the region. As a result, the reviving Maturidy doctrine had to compete with the Salafi ideology, backed up by good financial supports.

The Islamic development in Tatar cannot be separated from the roles of madrasa (educational institutions) established in this region. The madrasa in Chistopol headed by Gabdulhak Hazrat Samatov became a pioneer of Muslim professional education. At that time Samatov worked as the main muhtasib (main imam) of Tatarstan and at the same time held the positon of Imam-Khatib of Chistopol mosque. It was the mosque where at the end of the 1990-s the first Muslim student group, consisting of 20 members, was formed. The madrasa moved to Kazan a year later and since 1993 was officially registered as the madrasa of the Mosque of the thousandth anniversary of adoption of Islam ${ }^{16}$.

14 "New World," October 1995, No. 7 edition, p.15.

${ }^{15}$ Mukhametshin, Tatars and Islam in The XX Century, p.162-163.

${ }^{16} \mathrm{~V}$. Yakupov, Islam in Tatarstan in The 90th (Kazan: Iman, 2005), p.106-107. 
The madrasa "Yoldyz" in the city of Naberezhniy Chelny became the second educational institution initiated and headed by Idris Galyautdinov. ${ }^{17}$ The third madrasa called "Muhammadiya" was registered on the $20^{\text {th }}$ of August 1993 and became the largest Muslim educational institution. It was the first Muslim educational institution that provided education for women as well as full-time education and education by correspondence ${ }^{18}$.

The stage of extensive development of the Muslim educational system was completed with the opening of Russian Islamic University in July 1998 which was established by the Council of Muftis of Russia, Muslim Religious Board of the Republic of Tatarstan, the Institute of History at the Academy of Sciences of Tatarstan.

The year 2006 became the turning point for the study and dissemination of the teachings of al-Maturidy in Russia as Professor Rafik Mukhametshin was elected as the rector of the Russian Islamic University. In this year, a research on commentary on the text of aqida by Imam anNasafi began. Later on, that commentary was included into the cirruculum of the madrasa "Muhammadiya".

In 2011 when Ildus Hazrat Faizov was elected as a new mufti and head of Muslim Religios Board of the Republic of Tatarstan, the Maturidy teaching was declared as the traditional doctrine of all Muslims in Tatarstan ${ }^{19}$ Ever since, it was made compulsory in all madrasas controlled by the Spiritual Board of Muslims of the Republic of Tatarstan.

Invaluable contribution to the revival of the teachings of alMaturidy during the post-Soviet period was made by Waliullah Hazrat Yakupov who headed the publishing house "Iman" for years, up to his assassination in 2013. His publishing house was the first that published scientific articles on the Maturidy teaching as the traditional teaching of the Tatars. In 1999 the book of the German researcher Ulrich Rudolph titled "al-Maturidy and Sunni theology in Samarkand" was republished. Later in 2006, the translation of the commentary on Imam Nasafi's text of aqida by the Iraqi theologian 'Abd al-Malik' Abd al-Rahman al-Sa'di was published.

\footnotetext{
${ }^{17}$ Ibid., p.107.

${ }^{18}$ Ibid., p.108.

${ }^{19} \mathrm{http}$ ://islam_today.ru/veroucenie/veroubezdenie/polnyj_spisok_knig_po_a kyde_imama_azama_i_imama_maturidi/
} 
Later in 2008, the translation of the commentary by Sh. Mardzhani on the same text was made by Sh. Mardzhani Institute of History.

Today, the teaching aids and works (of Abu Mansur al-Maturidi are included to the curriculum of the Muslim educational institutions of Tatarstan. The publishing house "Huzur" founded by the Muslim Spiritual Board of Muslims of the Republic of Tatarstan, is now working on the translation of "Kitab al-Tawhid" and "Ta'vilat Ahl Sunnah". Also, in order to promote al-Maturidy' steachings Muslims in Tatarstanhe actyvely use the electronic and print media.

However, at the same time, dakwah activities by the Salafis leaders are also pronounced in today's Tatar., This is evidenced by the famous website http://abuhanifa.ru, which does not only promote Abu Hanifa's doctrine, but at the same time aslo contains critics of the Maturidy's doctrine.

\section{Conclusion}

This study concluded that the history of al-Maturidy theological teachings in the Volga region consisted of five periods. It rapidly developed during the pre-Mongolian and Mongolian periods. However, it did not develop after the fall of Kazan in 1552 and until the end of the 18th century. Starting from the late 18 th century until the first quarter of the 20th century, there was a sense of revival for the al-Maturidy doctrine in the region, which was yet to be followed by a decline during the Soviet period. The post-Soviet period can be described as the period of spiritual quest, and comprehension of the legacy. The spiritual quest resulted in the spread of the Salafi doctrine in Tatarstan, while comprehension of the legacy leads to the revival of the Hanafi-Maturidy tradition. As for the present state of the Maturidy tradition, we can see that it is actively promoted, analyzed and studied.

Despite this, socio-political changes had a significant impact on both the flourishing and decline of Abu Mansur al-Maturidy's teachings in the region. The main reasons for the decline were the policy of forced Christianization after the conquest of Kazan and the spread of Communist ideology after the collapse of the Russian Imperia. Meanwhile, the Renaissance of Maturidy tradition in the region was often associated with the processes of liberalization and democratization of the society. 


\section{References}

Adygamov, R., D. Shagaviev, A. Khayrutdinov, and L. Almazova. The History of Islamic Thought in The Volga-Ural Region. Kazan: Institute of History, 2011.

Fadlan, A. Ibn. Ibnu Fadlan's Journey to The Volga. Moscow: Publishing House of USSR Academy of Sciences, 1939.

Gormez, M. "Musa Carullah's Understanding of Sunnah.” In Musa Carullah Bigiyef on the 50th Anniversary of His Death. Ankara: TRF Publications, 2002.

Kemper, Michael. "Sihābuddīn Al-Margānī as a Religious Scholar, Muslim CUlture in Russia and Central Asia From The 18th to The Early 20th Centuries." In Islamic Studies, edited by Michael Kemper, Anke Von Kugelgen, and Dmitry Yermakov. Berlin: Klaus Schwarz Verlag, 1996.

- - - Sufis Und Gelehrte in Tatarien Und Baschkirien, 1789-1899, Der Islamiche Diskurs Unter Russicher Herrschaft. Berlin: Schwarz Verlag, 1998.

M. Gormez. "Tradition of Novation in Islam and Musa Carullah Bigiyef." In Musa Carullah Bigiyef on The 50th Anniversary of His Death, Ankara: TRF Publications, 2002.

Marash, I. Religious Renewal in The Turkic World (1850-1917). Kazan: Iman, 2005.

Marjani, Sh. Mustafad Al-Akhbar Fi Ahvali Kazan and Va Bulgar. Kazan: Domrovskiy, 1900.

Mukhametshin, R.M. Islam in The Midle Volga Region: History and Modernity. Kazan: The Master Line, 2001.

-__. Tatars and Islam in The XX Century. Kazan: TBP, 2003.

Rasulev, G. The Islam. Chelybinsk: The Trust, 2014.

Rudolph, Ulrich. Al-Maturidy and The Development of Sunni Theology in Samarqand. Leiden: Brill, 2015.

Yakupov, V. Islam in Tatarstan in the 90th. Kazan: Iman, 2005.

"New World," October 1995, No. 7 edition.

http://islam-today.ru/veroucenie/veroubezdenie/polnyj_spisok_knig_ po_akyde_imama_azama_i_imama_maturidi/. 